\title{
Soil bulk density and biomass partitioning of Brachiaria decumbens in a silvopastoral system
}

\author{
Domingos Sávio Campos Paciullo ${ }^{1 *}$; Carlos Renato Tavares de Castro ${ }^{1}$; Carlos Augusto \\ de Miranda Gomide ${ }^{1}$; Priscila Beligoli Fernandes ${ }^{1}$; Wadson Sebastião Duarte da Rocha ${ }^{1}$; \\ Marcelo Dias Müller'; Roberto Oscar Pereyra Rossiello \\ ${ }^{1}$ Embrapa Gado de Leite, R. Eugênio do Nascimento, 610 - 36038-330 - Juiz de Fora, MG - Brasil. \\ ${ }^{2}$ UFRRJ/Inst. de Agronomia - Depto. de Solos, Rod. BR-465, km 07 - 23851-970 - Seropédica, RJ - Brasil. \\ *Corresponding author < domingos@cnpgl.embrapa.br>
}

\begin{abstract}
Shade in silvopastoral systems improves the thermal comfort of animals, but it may also affect the pasture productivity and can contribute to soil compaction in the shaded areas due to the increase in the number of animals looking for comfort. The effect of grazing at various distances from tree rows (under the tree canopy, at 6 and at $12 \mathrm{~m}$ away from the trees) on the soil bulk density and on the aerial and root biomass of Brachiaria decumbens was evaluated in both the dry and the rainy seasons. The study was carried out on an Orthic Ferralsol in a randomized block design with two replications. Tree rows were composed of Eucalyptus grandis and Acacia mangium species, and the paddocks were submitted to a rotational stocking management, using Holstein $($ Bos taurus $) \times$ Zebu (Bos indicus) heifers. The shade intensity in the pasture decreased with an increasing distance from the tree row. Soil bulk density did not vary with the distance from the tree row, but varied seasonally, being greater in the rainy season $\left(1.47 \mathrm{~g} \mathrm{~cm}^{-3}\right)$ than in the dry season $\left(1.28 \mathrm{~g} \mathrm{~cm}^{-3}\right)$. Green forage and root mass, expressed as dry matter, were lower under the tree canopy and were greater in the rainy season. There were decreases of 22.3 and $41.4 \%$ in the aerial and root biomasses, respectively, in the tree rows. The greatest shoot/root ratio for $B$. decumbens under moderate and intensive shading indicates a modification in the forage biomass allocation pattern that favours the aerial development in detriment of the root system. Key words: forage mass, root mass, soil compaction, shading, shoot/root ratio
\end{abstract}

\section{Densidade do solo e partição de biomassa de Brachiaria decumbens em um sistema silvopastoril}

\begin{abstract}
RESUMO: O sombreamento em sistemas silvipastoris concorre para o conforto térmico dos animais; no entanto pode afetar a produção do pasto e contribuir para a compactação do solo, pelo aumento da concentração de animais nas áreas sombreadas. Avaliou-se o efeito da distância do renque de árvores (sob a copa das árvores, 6 e $12 \mathrm{~m}$ de distancia das árvores) na densidade do solo e na biomassa aérea e de raízes de Brachiaria decumbens, nas épocas seca e chuvosa. O estudo foi conduzido num Latossolo Vermelho-Amarelo no delineamento em blocos casualizados, com duas repetições. A faixa de árvores foi composta pelas espécies Eucalyptus grandis e Acacia mangium, e os piquetes foram manejados com novilhas Holandês (Bos taurus) $\times$ Zebu (Bos indicus), sob lotação rotativa. A intensidade de sombreamento foi decrescente com o distanciamento do renque de árvores. A densidade do solo não variou com a distância do renque de árvores, mas sim com a época do ano, tendo sido maior na época chuvosa $\left(1,47 \mathrm{~g} \mathrm{dm}^{-3}\right)$ do que na seca $\left(1,28 \mathrm{~g} \mathrm{dm}^{-3}\right)$. As massas secas de forragem verde e de raízes foram menores sob a copa das árvores e maiores na época chuvosa do que na seca. Na faixa arborizada houve reduções de 22,3 e 41,4\% na biomassa aérea e de raízes, respectivamente. A maior relação parte aérea/raiz da $B$. decumbens à sombra expressa uma modificação no padrão de alocação de biomassa na forrageira, que prioriza a formação da parte aérea, em detrimento do sistema radicular.

Palavras-chave: biomassa de raiz, compactação do solo, massa de forragem, relação parte aérea/raiz, sombreamento
\end{abstract}

\section{Introduction}

In many parts of the world, the use of silvopastoral systems has been suggested to ensure sustainability in animal production systems due to their potential to increase soil fertility, improve forage quality, promote animal thermal comfort and to provide income diversification for the producer (Chang et al., 2002; Lehmkuhler, et al., 2003; Ribeiro et al., 2007; Rozados-Lorenzo et al., 2007). Nevertheless, the shade provided by trees may affect grass es- tablishment and plant growth depending on the change in the availability of sunlight (Paciullo et al., 2008; Soares et al., 2009). Some authors have shown changes in the allocation pattern of the photo-assimilates that are needed for the production of grass biomass when the grass is exposed to shade, such as decreases in root production and, consequently, a closer relationship between the aerial and the root biomass (Guenni et al., 2008).

In tropical silvopastoral systems, animals tend to gather in shaded places, especially during the summer 
months (Bennett et al., 1985; Paes Leme et al., 2005). This fact suggests that shaded places may be more susceptible to soil compaction due to animal trampling. The compaction process is associated with a soil volume reduction caused by the pressure exerted on the soil, which results in an increase in the total soil density (Azenegashe et al., 1997), an alteration in the soil pore size distribution (Dexter, 1988) and a greater resistance to root penetration. The degree of compaction is influenced by soil texture and water content, pasture height management, forage mass and by the stocking rate (Defossez and Richard, 2002).

Compaction may affect the root development by increasing the sensitivity of the forage species to water deficits and by limiting access to nutrients in the sub superficial soil strata (Beulter and Centurion, 2004). This study aimed to assess the impact of animal grazing on the soil bulk density and on the herbage biomass under various shading regimes, in a silvopastoral system, during both the dry and rainy seasons.

\section{Material and Methods}

The study was carried out in Coronel Pacheco, state

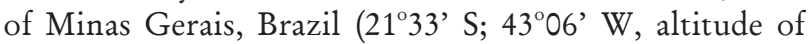
$410 \mathrm{~m}$ ) from June 2008 to March 2009. According to the Köppen climate classification, the predominant climate in the region is mesothermal. The soil in the experimental field is an Orthic Ferralsol (FAO, 2006) (Latossolo Vermelho-Amarelo, according to the Brazilian classification - EMBRAPA, 1999), with undulated relief. The soil texture characteristics for the $0-20 \mathrm{~cm}$ layer were: coarse sand $=100 \mathrm{~g} \mathrm{~kg}^{-1}$, fine sand $=280 \mathrm{~g} \mathrm{~kg}^{-1}$, silt $=$ $190 \mathrm{~g} \mathrm{~kg}^{-1}$ and clay $=430 \mathrm{~g} \mathrm{~kg}^{-1}$. Meteorological data (Figure 1) were obtained from an agrometeorological station located about $500 \mathrm{~m}$ from the assessed pasture.

The assessments were made in a 4-ha silvopastoral system that was established in November 1997. The area has a mountainous topography, with a slope of about $30 \%$. The assessed plots were composed of Brachiaria decumbens cv. Basilisk grass intercropped by the Acacia mangium and Eucalyptus grandis arboreal species mea-

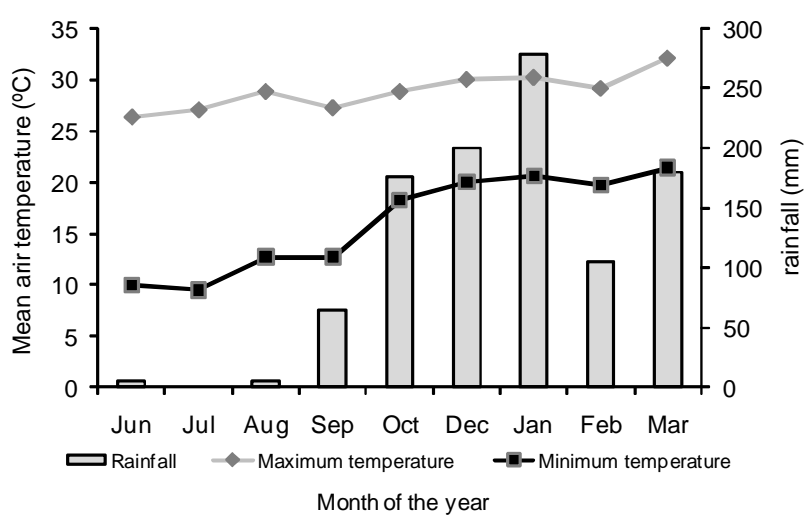

Figure 1 - Mean monthly rainfall and daily air temperature at the experimental site from June 2008 to March 2009. suring about 25 and $20 \mathrm{~cm}$ in diameter at breast height and 14 and $22 \mathrm{~m}$ in height, respectively. The trees were arranged in $10 \mathrm{~m}$-wide strips, each strip included $3 \times 3$ $\mathrm{m}$ spaced rows. The tree species were alternated within each row in each of the strips. The distance between two ranks of trees was $30 \mathrm{~m}$.

The trial was conducted in a randomized block design with three treatments $(0,6$ and $12 \mathrm{~m}$ from the tree rows) and evaluated in the dry and rainy seasons. Photosynthetically active radiation (PAR) measurements were made bimonthly using a LP 80 model Decagon ceptometer, on clear days, at 9h00, $12 \mathrm{~h} 00$ and $15 \mathrm{~h} 00$, to capture the day-to-day sunlight variation. Five PAR incidence readings were made for each distance from the tree row.

Applications of dolomitic limestone at the rate of $1,000 \mathrm{~kg} \mathrm{ha}^{-1}$, Araxa phosphate at $600 \mathrm{~kg} \mathrm{ha}^{-1}\left(5 \%\right.$ of $\mathrm{P}_{2} \mathrm{O}_{5}$ soluble in citric acid), simple superphosphate at $250 \mathrm{~kg}$ $\mathrm{ha}^{-1}$, potassium chloride at $100 \mathrm{~kg} \mathrm{ha}^{-1}$ and FTE (fitted trace elements) BR-16 (3.5\% of zinc, $1.5 \%$ of boron, $3.5 \%$ of copper and $0.40 \%$ of molibdenum) at $30 \mathrm{~kg} \mathrm{ha}^{-1}$ were made before planting the grass. After planting, no additional fertilizer or corrective treatments were applied to the pasture.

Between 1998 and 2000, the pasture was not grazed to ensure the initial growth of the arboreal species. The pastures were divided into 0.5 ha plots. Between 2001 and 2003, they were used for the grazing of non-lactating cows, alternating grazing and rest periods of five and 45 days, respectively. From January 2003 to March 2009, the areas were managed with Holstein $\times$ Zebu heifers, with an initial live body weight of $250 \mathrm{~kg}$, in a rotational stocking management, with seven days of grazing and 35 and 49 days of rest period, in the rainy and dry seasons, respectively. The average pasture height at the beginning and at the end of the grazing period was 37 and $22 \mathrm{~cm}$, respectively. The average number of heifers per hectare varied between 1.48 and 2.53, corresponding to stocking rates between 0.8 and 1.6 animal unit $\mathrm{ha}^{-1}$, in the dry and rainy seasons, respectively.

The assessments of the grass were made during the dry (June to September 2008) and rainy (November 2008 to March 2009) seasons. The forage mass was estimated for each grazing cycle from the cuts made in the pregrazing condition. Four samples were collected from each plot, using a $0.5 \times 0.5 \mathrm{~m}$ metal frame along a line parallel to the tree row. Cuts were made at $5 \mathrm{~cm}$ from the ground level in four areas that were representative of the average sward condition (leaf canopy height) at the time of sampling. To obtain the average sward condition, the leaf canopy height was measured using systematic readings on a $1 \mathrm{~m}$ ruler graduated in centimeters ( 20 points of measurement) covering the entire area of each plot. Readings were taken from ground level, considering the upper surface of the leaf canopy around the ruler as a reference. After cutting, the samples were weighed fresh and then subsampled. The subsamples were also weighed fresh. Each subsample was hand dis- 
sected into live and dead material. Each component was dried separately in a forced-draught oven at $55^{\circ} \mathrm{C}$ for 72 $\mathrm{h}$ and was then weighed. The dry matter content of the herbage was calculated from the dry weights of the subsamples and their components, and the herbage mass was calculated accordingly.

Samples of the root system were collected with a 10 $\mathrm{cm}$ diameter and $10 \mathrm{~cm}$ high steel cylindrical soil sampler. Two samples were collected per plot. To study the root distribution through the soil profile in the same field, data points were taken using ten soil cores consecutively from the top of the soil to a depth of $100 \mathrm{~cm}$. The samplings were performed in August 2008 (dry season) and in February 2009 (rainy season). The roots contained in the samples were recovered with low pressure under a water jet using a sieve plate (Böhm, 1979). Samples were dried in an air-forced oven at $55^{\circ} \mathrm{C}$ for $72 \mathrm{~h}$ and then weighed. The effective rooting depth was defined as corresponding to $80 \%$ of the total root weight between the depths of $0-100 \mathrm{~cm}$. The pasture shoot/root ratio was calculated as the relation between the total forage mass and the root mass, with both expressed as dry matter.

The effect of soil compaction was obtained through the calculation of the bulk density, using a volumetric ring. The soil density was estimated on the same dates of the root system sampling. The samples were taken in two positions in each plot, adjacent to the points used for the root collection. Soil cores from each $10 \mathrm{~cm}$ layer, down to $100 \mathrm{~cm}$ in depth, were weighed and a sub-sample was dried at $105^{\circ} \mathrm{C}$ to determine the soil water content.

Data were analyzed using the Sisvar program, version 4.3. An analysis of variance was performed using the Repeated Measures option (dry and rainy seasons). The means were compared using the Tukey test at 5\% significance. Soil bulk density and root biomass were considered the effects of the soil profile (from 0 to 100 $\mathrm{cm}$ ), in addition to the distance from the tree row and the season of the year. When appropriate, regression analyses were performed on the soil profile data for soil bulk density and root biomass characteristics.

\section{Results and Discussion}

The measured percentages of shade, in relation to the PAR under full sunlight, were 60,29 and $16 \%$, at the distances of $O$ (directly under tree canopy), 6 and $12 \mathrm{~m}$, respectively. The average soil bulk density was greater $(p$ $\leq 0.001)$ in the rainy season $\left(1.47 \mathrm{~g} \mathrm{~cm}^{-3}\right)$ than in the dry season $\left(1.28 \mathrm{~g} \mathrm{~cm}^{-3}\right)$. Similarly, the soil water content was higher $(p=0.023)$ in the rainy season $(24.5 \%)$ than in the dry season (18.8\%), reflecting the greater pluvial precipitation during the rainy season months. Some studies have shown a positive correlation between the soil water content and soil compaction (Greenwood and McKenzie, 2001; Imhoff et al., 2000; Leão et al., 2004; Lima et al., 2004), which could explain the higher density obtained in the rainy season. In addition, the stocking rate in the rainy season was twice that of the dry season. Thus, the higher stocking rate, associated with a greater amount of soil water, favored the greater soil density observed in the rainy season.

Soil compaction may affect important ecological properties, such as water and air flow, in addition to affecting root and plant growth. Nevertheless, the critical limits of soil bulk density for crop growth depend upon soil texture, mineralogy, particle shape and organic matter (Reichert et al., 2009). The critical bulk densities calculated in the present study, according to the equations proposed by Reichert et al. (2009) and to the soil clay content in the experimental area (43\%), ranged from 1.49 to $1.55 \mathrm{~g} \mathrm{~cm}^{-3}$. The highest value obtained in the rainy season $\left(1.47 \mathrm{~g} \mathrm{~cm}^{-3}\right)$ still remained below these critical densities, indicating that the soil bulk density did not affect the root growth.

Soil bulk density did not vary $(p>0.05)$ with the distance from the tree row (average values of 1.38; 1.37; $1.37 \mathrm{~g} \mathrm{~cm}^{-3}$, for the distances 0,6 and $12 \mathrm{~m}$ away from the tree row, respectively) or with the interaction of the distance from tree row and soil depth. The hypothesis that a larger concentration of animals in the areas with more intensive shade (Bennett et al., 1985; Paes Leme et al., 2005) increases soil density due to more frequent trampling of animal hoof was not confirmed.

Two aspects must be considered in the explanation of the similarity between the soil density values at different distances from the tree row. First, the silvopastoral system was managed over the last 6 years with heifers and low stocking rates. The pressure exerted by the trampling of heifers is lower than that of adult animals (Cantarutti et al., 2001), and the use of low stocking rates reduces the amount of trampling per unit soil surface, which in turn, reduces the impact of animal movement on soil density (Naeth et al., 1990). The probability that trampling by animal hoof occurs at the same location on the ground is increased in intensive pastoral systems with high stocking rates (Mapfumo et al., 1999), which in turn, increases the soil density values between 7 and 18\% (Azenegashe et al., 1997). Second, the greater amount of litter under the tree canopy might have reduced the impact caused by animal movement in areas with intensive shade. The soil cover promotes physical protection, reducing the impact of trampling (Greenwood and McKenzie, 2001; Muller et al., 2001).

Soil bulk density varied $(p=0.041)$ inversely with soil depth, independent of the distance from the tree row, according to the regression equation $\breve{Y}=1.45-0.0015$ $\times\left(\mathrm{R}^{2}=0.81\right)$, where $\times$ corresponds to depth $(\mathrm{cm})$. This result demonstrates that trampling by animals caused a greater impact on the soil density in the superficial strata, regardless of the distance from the tree row. In fact, soil compaction due to animal movement occurs on the superficial soil layer, varying between 3 and $15 \mathrm{~cm}$ (Lanzanova et al., 2007; Bertol et al., 2000).

The green forage mass (GFM), the dead material (DMA) and the total forage mass (TFM) varied $(p \leq 0.05)$ according to the season and the distance from the tree row (Table 1). The highest GFM value was obtained in 
the rainy season due to the optimal growth supported by meteorological conditions. The greatest amounts of DMA and TFM were observed in the dry season. The unexpectedly high TFM can be explained by the high contribution of the DMA during the dry season, with the high dry matter percentage. The DMA contributions to the TFM were 14.3 and $78.8 \%$ for the rainy and the dry season, respectively. In addition, the dry matter percentage of the GFM was higher during the dry (45.3\%) as compared to the rainy $(22.3 \%)$ season.

The values of the three variables related to the aerial portion of the plant (GFM, DMA and TFM) were reduced at the sites with the highest percentage of shade (60\% under tree canopy), which is consistent with other studies that showed reduced grass growth above $35-40 \%$ shade (Andrade et al., 2004; Guenni et al, 2008; Paciullo et al., 2007). On the other hand, the GFM was similar at 12 and $6 \mathrm{~m}$ distances, with an incidence of 16 and 29\% shade, respectively. In fact, shade percentages up to 30 $35 \%$ do not affect grass growth, although they may cause a slight decrease in forage production when the forage species is moderately tolerant to shade (Andrade et al., 2004; Paciullo et al., 2008; Soares et al., 2009). Brachiaria decumbens is tolerant to shading and responds with morpho-physiological adjustments, such as increases in the specific leaf area and the leaf elongation rate, which allow for productivity maintenance even under limited sunlight conditions (Dias-Filho, 2000; Guenni et al., 2008; Paciullo et al., 2008).

The effective depth of the root system did not vary with the treatments, but root density was greater in the rainy season compared to the dry season, as well as at the most distant point from the tree row $(12 \mathrm{~m})$, under less shade (Table 2). An analysis of the root distribu- tion through the soil profile, between 0 and $100 \mathrm{~cm}$, showed that the root mass was consistently greater 12 $m$ away from the tree rows only in the $0-20 \mathrm{~cm}$ deep layer, regardless of the season. In the rainy season, an increase in the root mass between the 20 and $40 \mathrm{~cm}$ depth was found in areas under smaller amount of shade; the values were similar at other depths (Figure 2).

In silvopastoral systems, competition for growth resources is inevitable between the trees and the pasture species. The significance and the level of competition are determined by climate, management, soil type and species. Although reductions in the soil water content under forests versus pastures may occur (Yunusa et al., 1995), in silvopastoral systems that are established in humid environments, the primary form of competition is for light (Rao et al., 1998). Maximum temperatures in the litter and on the surface of the soil under the shade were lower than the average values found under full sun in tropical areas (Belsky and Canham, 1994; Wilson, 1996). Therefore, the soil that is under shade dries slower after rain than the soil that is under full sun and this benefit of increased soil moisture could alleviate plant water stress (Wilson, 1996; 1998).

Because soil bulk density under the trees did not reach the critical values needed to affect root growth and water stress by competition between tree and pasture likely did not occur, it can be inferred that shade was the main cause for root biomass reduction in the top 20 $\mathrm{cm}$ of the soil under moderate and intensive shading. Plants under shade usually modify their biomass allocation pattern, favoring the production of the aerial parts in detriment to roots, to maximize sunlight exposure under limited radiation conditions (Dias-Filho, 2000; Durr and Rangel, 2000; Guenni et al., 2008).

Table 1 - Average values of green forage mass (GFM), dead material (DMA) and total forage mass (TFM) of B. decumbens swards, according to the season of the year and distance from the tree row.

\begin{tabular}{|c|c|c|c|c|c|}
\hline \multirow{2}{*}{ Dry mass } & \multicolumn{2}{|c|}{ Season of the year } & \multicolumn{3}{|c|}{ Distance from the tree row $(\mathrm{m})$} \\
\hline & Dry & Rainy & 0 & 6 & 12 \\
\hline & . & 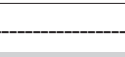 & ing cycle & - & 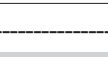 \\
\hline GFM & $526 \mathrm{~b}$ & 1,496 a & $813 \mathrm{~b}$ & $1,194 \mathrm{a}$ & $1,103 \mathrm{a}$ \\
\hline DMA & 1,798 a & $368 \mathrm{~b}$ & $965 \mathrm{~b}$ & $1,397 \mathrm{a}$ & $1,203 \mathrm{a}$ \\
\hline TFM & $2,324 \mathrm{a}$ & $1,864 \mathrm{~b}$ & $1,778 \mathrm{~b}$ & $2,591 \mathrm{a}$ & $2,306 \mathrm{a}$ \\
\hline
\end{tabular}

Means followed by the same lower case letter in rows for either season of the year or distance from the tree row are not different $(p>0.05)$.

Table 2 - Effective rooting depth, root density and shoot/root (S/R) ratio of $B$. decumbens swards, according to the season of the year and distance from the tree row.

\begin{tabular}{|c|c|c|c|c|c|}
\hline \multirow{2}{*}{ Characteristic } & \multicolumn{2}{|c|}{ Season of the year } & \multicolumn{3}{|c|}{ Distance from the tree row $(\mathrm{m})$} \\
\hline & Dry & Rainy & 0 & 6 & 12 \\
\hline Effective depth (cm) & $32.5 \mathrm{a}$ & $46.6 \mathrm{a}$ & $43.9 \mathrm{a}$ & $42.7 \mathrm{a}$ & $32.1 \mathrm{a}$ \\
\hline Root density $\left(\mathrm{g} \mathrm{m}^{-3}\right)$ & $0.30 \mathrm{~b}$ & $0.52 \mathrm{a}$ & $0.34 \mathrm{~b}$ & $0.31 \mathrm{~b}$ & $0.58 \mathrm{a}$ \\
\hline $\mathrm{S}: \mathrm{R}$ & $1.33 \mathrm{a}$ & $0.57 \mathrm{~b}$ & $1.00 \mathrm{a}$ & $1.21 \mathrm{a}$ & $0.64 \mathrm{~b}$ \\
\hline
\end{tabular}

Means followed by the same lower case letter in rows for either season of the year or distance from the tree row are not different (p>0.05). 


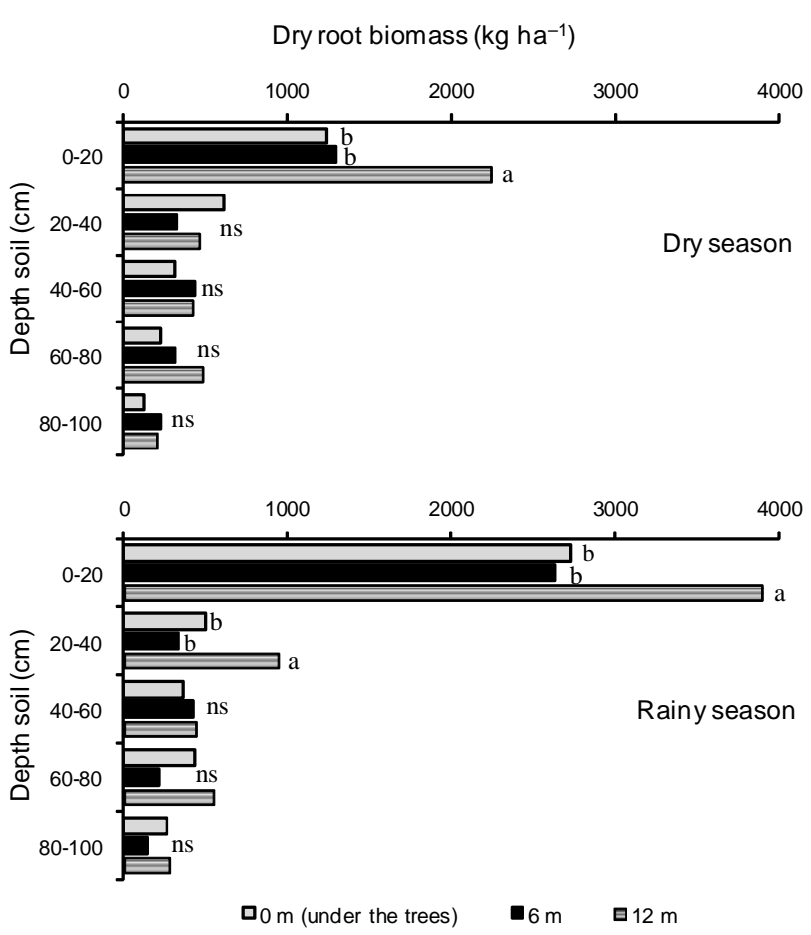

Figure 2 - Root distribution of $B$. decumbens in soil profile, according to the season of the year and distance from the tree row. Means followed by different letters in each season of the year and depth soil layer are different $(p<0.05)$. ns $=$ not significant $(p>0.05)$.

The reduction in aerial biomass in intensive shading was $22.3 \%$ in relation to the $12 \mathrm{~m}$ distance, whereas the relative reduction in the root mass, caused by shade, was $41.4 \%$. The most significant decrease of root mass in relation to the aerial parts of the plant was reflected in the higher shoot/root ratio for plants growing under the tree canopy and at a distance of $6 \mathrm{~m}$ away from tree rows, in relation to those plants growing under less shade (Table 2).

The substantial reduction in root mass may cause pastures to become vulnerable to environmental stresses that require strong interference from the root system for regrowth (Dias-Filho, 2000). In the short run the smaller allocation of biomass to the root system may reduce the pasture tolerance to water deficits and, in the long run, it may threaten the maintenance of the pasture due to the fact that the survival of grazed vegetation is at risk (Dias-Filho, 2000; Guenni et al., 2008). More detailed studies looking at the interactions of the intensity and the frequency of grazing, the stocking rate and the fertilization regimes would be necessary to corroborate the above mentioned hypotheses.

\section{Conclusions}

Soil bulk density did not vary with the distance from the tree rows in the grazing pasture within the silvopastoral system that was managed with heifers for 6 years under low stocking rates. However, on the strip of land within the rows of trees, and within $6 \mathrm{~m}$ from these rows, there was a change in the biomass allocation pattern of $B$. decumbens that favored the development of the aerial parts of the plant in detriment to the root system.

\section{Acknowledgements}

To FAPEMIG for partial funding of this research.

\section{References}

Andrade, C.M., Valentin, J.F., Carneiro, J.C., VAZ, F.A. 2004. Growth of tropical forage grasses and legumes under shade. Pesquisa Agropecuária Brasileira 39: 263-270. (in Portuguese, with abstract in English).

Azenegashe, O.A.; Allen, V.; Fontenot, J. 1997. Grazing sheep and cattle together or separately: effect on soil and plants. Agronomy Journal 89: 380-386.

Belsky, A.J.; Canham, C.D. 1994. Forest gaps and isolated savanna trees. Bioscience 44: 77-84.

Bennett, I.L.; Finch, V.A.; Holmes, C.R. 1985. Time spend in shade and its relationship with physiological factors of thermoregulation in three breeds of cattle. Applied Animal Behaviour Science 13: 227-236.

Bertol, I.; Almeida, J.A.; Almeida, E.X.; Kurtz, C. 2000. Soil physic properties related to forage offer levels of dwarf elephant grass cv. Mott. Pesquisa Agropecuária Brasileira 35: 1047-1054. (in Portuguese, with abstract in English).

Beulter, A.N.; Centurion, J.F. 2004. Effect of soil compaction in root development and in soybean yield. Pesquisa Agropecuária Brasileira 39: 581-588. (in Portuguese, with abstract in English).

Böhm, W. 1979. Methods of Studying Root Systems. SpringerVerlag, Berlin, Germany. 188 p.

Cantarutti, R.B; Nascimento Jr., D.; Costa, O.V. 2001. Impact of animal on the soil: compaction and nutrient recycling. p. 826837. In: Mattos, W.R.S., ed. Livestock production in the view of Brazilians. FEALQ, Piracicaba, Brazil. (in Portuguese).

Chang, S.X.; Amatya, G.; Beare, M.H.; Mead, D.J. 2002. Soil properties under a Pinus radiate: ryegrass silvopastoral system in New Zealand. Part I. Soil N and moisture availability. Agroforestry Systems 54: 137-147.

Defossez, P., Richard, G. 2002. Models of soil compaction due to traffic and their evaluation. Soil Tillage Research 67: 41-64.

Dexter, A.R. 1988. Advances in characterization of soil structure. Soil and Tillage Research 11: 199-238.

Dias-Filho, M. 2000. Growth and biomass allocation of the $\mathrm{C}_{4}$ grasses Brachiaria brizantha and B. humidicola under shade. Pesquisa Agropecuária Brasileira 35: 2335-2341.

Durr, P.A.; Rangel, J. 2000. The response of Panicum maximum to a simulated subcanopy environment. 1. Soil $\mathrm{x}$ shade interaction. Tropical Grasslands 34: 110-117.

Empresa Brasileira de Pesquisa Agropecuária [EMBRAPA]. 1999. Brazilian System for Soil Classification. Centro Nacional de Pesquisa de Solos, Rio de Janeiro, RJ, Brazil. (in Portuguese).

Food and Agriculture Organization [FAO]. 2006. World reference base for soil resources 2006: a framework for international classification, correlation and communication. FAO, Rome, Italy. 145 p. (World Soil Resources Report, 103).

Greenwood, K.L; McKenzie, B.M. 2001. Grazing effects on soil physical properties and the consequences for pastures: a review. Australian Journal of Experimental Agriculture 41: 1231-1250.

Guenni, O.; Seiter, S.; Figueroa, R. 2008. Growth responses of three Brachiaria species to light intensity and nitrogen supply. Tropical Grasslands 42: 75-87.

Imhoff, S.; Silva, A.P.; Tormenta, C.A. 2000. Applications of the resistance curve in the control of the physical quality of soils under grass. Pesquisa Agropecuária Brasileira 35: 1493-1500. (in Portuguese, with abstract in English). 
Lanzanova, M.E.; Nicoloso, R. da S.; Lovato, T.; Eltz, F.L.F.; Amado, T.J.C.; Reinert, D.J. 2007. Soil physical attributes in integrated cattle raising-crop production system under no-tillage. Revista Brasileira de Ciência do Solo 31: 1131-1140. (in Portuguese, with abstract in English).

Leão, T.P.; Silva, A.P.; Macedo, M.C.M.; Imhoff, S.; Euclides, V.P.B. 2004. Least limiting water range in the evaluation of continuous and short-duration grazing systems. Revista Brasileira de Ciência do Solo 28: 415-423. (in Portuguese, with abstract in English).

Lehmkuhler, J.W.; Felton, E.E.D.; Schimidt, D.A.; Bader, K.J.; Garret, H.E.; Kerley, M.S. 2003. Tree protection methods during the silvopastoral-system establishment in midwestern USA: cattle performance and tree damage. Agroforestry Systems 59: 35-42.

Lima, C.L.R.; Silva, A.P.; Imhoff, T.P.; Leão, T.P. 2004. Soil compressibility under non-irrigated and irrigated short duration grazing systems. Revista Brasileira de Ciência do Solo 28: 945951. (in Portuguese, with abstract in English).

Mapfumo, E.; Chanasyk, D.S.; Naeth, M.A.; Baron, V.S. 1999. Soil compaction under grazing of annual and perennial forages. Canadian Journal of Soil Science 79: 191-199.

Muller, M.M.; Guimarães, M.F.; Desjardins, T.; Martins, P.F.S. 2001. Pasture degradation in the Amazon region: soil physical properties and root growth. Pesquisa Agropecuária Brasileira 36: 1409-1418. (in Portuguese, with abstract in English).

Naeth, M.A., Pluth, D.J., Chanasyk, D.S., Bailey, A.W., Fedkenheuer, A.W. 1990. Soil compacting impacts of grazing in mixed prairie and fescue grassland ecosystems of Alberta. Canadian Journal of Soil Science 70: 157-167.

Paciullo, D.S.C.; Campos, N.R.; Gomide, C.A.M.; Castro, C.R.T.; Tavela, R.C.; Rossiello, R.O.P. 2008. Growth of signalgrass influenced by shading levels and season of the year. Pesquisa Agropecuária Brasileira 43: 317-323. (in Portuguese, with abstract in English).

Paciullo, D.S.C.; Carvalho, C.A.B.; Aroeira, L.J.M.; Morenz, M.J.F.; Lopes, F.C.F.; Rossiello, R.O.P. 2007. Morphophysiology and nutritive value of signalgrass under natural shading and full sunlight. Pesquisa Agropecuária Brasileira 42: 573-579. (in Portuguese, with abstract in English).
Paes Leme, T.M.; Pires, M.F.A.; Verneque, R.S.V.; Alvim, M.J.; Aroeira, L.J.M. 2005. Behavior of holstein x zebu crossbreed cows grazing Brachiaria decumbens in a silvipastoral system. Ciência e Agrotecnologia 29: 668-675. (in Portuguese, with abstract in English).

Rao, N.L.; Nair, P.K.R.; Ong, C.K. 1998. Biophysical interactions in tropical agroforestry systems. Agroforestry Systems 38: 3-50.

Reichert, J.M.; Suzuki, L.E.A.S.; Reinert, D.J.; Horn, H.; Hakansson, I. 2009. Reference bulk density and critical degree of compactness for no-till crop production in subtropical highly weathered soils. Soil and Tillage Research 102: 242-254.

Ribeiro, S.C.; Chaves, H.M.L.; Jacovine, L.A.G.; Silva, L. 2007. Estimation of erosion reduction carried out by agrosilvopasture system and its economic contribution. Revista Arvore 31: 285293. (in Portuguese, with abstract in English).

Rozados-Lorenzo, M.J.; Gonzales-Hernandez, M.P.; Silva-Pando, F.J. 2007. Pasture production under different tree species and densities in an Atlantic silvopastoral system. Agroforestry Systems 70: 53-62.

Soares, A.B.; Sartor, L.R.; Adami, P.F.; Varella, A.C.; Fonseca, L.; Mezzalira, J.C. 2009. Influence of luminosity on the behavior of eleven perennial summer forage species. Revista Brasileira de Zootecnia 38: 443-451. (in Portuguese, with abstract in English).

Yunusa, I.A.M.; Mead, D.J.; Lucas, R.J.; Pollock, K.M. 1995. Process study in a Pinus radiata-pasture agroforestry system in a subhumid temperature environment. II. Analysis of dry matter yields in the third year. Agroforestry Systems 32: 185-204.

Wilson, J.R. 1996. Shade-stimulated growth and nitrogen uptake by pasture grasses in a subtropical environment. Australian Journal of Agriculture Research 47: 1075-1093.

Wilson, J.R. 1998. Influence of planting four tree species on the yield and soil water status of green panic pasture in subhumid south-east Queensland. Tropical Grassland 32: 209-220.

Received September 09, 2009

Accepted April 28, 2010 